\title{
PRELIMINAR REPORT ON THE PRESENCE OF TEGUMENTAR GLANDS IN THE THORAX OF MELIPONINAE BEES (HYMENOPTERA, APIDAE)
}

\author{
CRUZ-LANDIM, C. and REGINATO, R. D. \\ Departamento de Biologia, Instituto de Biociências de Rio Claro, Unesp, CEP 13506-900, Rio Claro, SP, Brazil \\ Correspondence to: Carminda da Cruz Landim, Departamento de Biologia, Instituto de Biociências de Rio Claro, \\ Unesp, CEP 13506-900, Rio Claro, SP, Brazil, e-mail: cclandim@life.unesp.br \\ Received September 03, 1997 - Accepted July 02, 1998 - Distributed February 23, 1999
}

(With 3 figures)

\begin{abstract}
This is a first report on the presence of glandular cells in the lateral tegument of the mesothorax of Meliponinae bees. The cells are of the insect class III glandular cells and are present in queens, workers and males. The glands are more developed in queens than in workers, and in workers than in males.
\end{abstract}

Key words: mesothorax, glands, tegument, male, worker, queen.

\section{RESUMO}

Relato preliminar da presença de glândulas tegumentares no tórax de abelhas da subfamília Meliponinae (Hymenoptera, Apidae)

Este é um primeiro relato sobre a presença de células glandulares no tegumento lateral do mesotórax de abelhas da subfamília Meliponinae. Trata-se de células glandulares de classe III que estão presentes em rainhas, operárias e machos. As glândulas são mais desenvolvidas nas rainhas que nas operárias e nestas mais que nos machos.

Palavras-chave: mesotórax, glândulas, tegumento, macho, operária, rainha.

\section{INTRODUCTION}

The bees have exocrine glands distributed overall body, some of them structured as distinct organs, as the glands of the salivary system, and others as modified epidermal cells: the tegumentary glands (Cruz-Landim, 1996).

The tegumentar or dermal glands were separated in three different classes by Noirot \& Queenedey $(1974,1991)$, two of them, the class I and III present in bees. The glands with class I cells are represented by zones of secretory epithelium along the tegumentar epidermis. Examples are the wax glands described by Dreyling (1903) and Rösh (1927) in the honeybee ventral abdomen.

The class III are represented by groups of globular secretory cells individually connected to the tegument by excretory canaliculi, as the scent glands of the VII tergite of the honeybee workers (Jacobs, 1924; McIndoo, 1914).

Along the time other glands of both classes were described by several authors in head and abdomen (Bordas, 1895; Heselhaus, 1922; Koschewnikov, 1900; Cruz-Landim, 1963; Renner \& Baumann, 1964; Cruz-Landim et al., 1980; Mota, 1982, 1988; Mota \& Cruz-Landim, 1988; Cruz-Landim \& Mota, 1993) in honeybee and meliponine bees. Cruz-Landim \& Silva de Moraes (1994) reported also the presence of both classes of glandular cells in the tibia of Apis mellifera, Melipona quadrifasciata anthidioides and Scaptotrigona postica.

To the thorax, Vison et al. (1986), Vinson (1994) \& Minckley (1994) reported the presence of a mesosomal glands in Xylocopini. According to Vinson (1994) this glands consist of an invagination of the intersegmental membrane between 
the propodeum and metatergum, forming a series of finger like pouches beneath the cuticle. The cells of this gland are type I. Other types of tegumentary glands in the bee's thorax are unknown. The sole gland described in this part of the body, in the imago, being the thoracic labial or salivary gland, that although having its secretory portion in this part, opens into the glossa. The scope of this paper is to report the presence and location of some tegumentar glands found in the thorax of some species of meliponine bees.

\section{MATERIAL AND METHODS}

Adult bees were collected in the hives, cooled to $4^{\circ} \mathrm{C}$ and their head, abdomen, wings and legs removed. The thoraxes (pro-podeum and thorax) were fixed in $4 \%$ paraformaldheyde in $0,1 \mathrm{M}$ phosphate buffer, $\mathrm{pH} 7.0$ for $5 \mathrm{~h}$ during which the samples were submited to vacuum in the first hour. The samples were washed in the buffer. For scanning electron microscopy (SEM), samples were dehydrated in a graded series of ethanol and critical point-dried, covered with gold and examined with a Jeol JMS P 15 electron microscope.

Samples for light microscopy were dehydrated until 95\% ethanol, embedded in JB4 historesin and sectioned with glass knives. The sections, $6 \mu \mathrm{m}$ thick were stained with hematoxylin and eosin.

\section{RESULTS AND DISCUSSION}

Studying histological sections of some meliponine bee's thorax we come across with the presence of glandular cells in the lateral mesothorax.

The Table 1 has the list of species examined and the way the glands occur in the adult individual components of the nest.

The glands are constituted by isolated unicelular secretory units and could be embodied in the Noirot \& Quennedey $(1974,1991)$ class III. These are gland cells of epidermal origin that have an intracellular canal, collector of secretion which are connected to the cuticle by an extracellular excretory canal. The glands are them made of groups of these secretory units or cells.

In the studied bees, the glandular cells groupments locate laterally in the mesothorax, below the wings (Fig. 1, 2A). The cells lay between the tegument and the segmentar muscles of the thorax (Fig. 2A, B). The excretory canaliculus opens to the exterior, among the thoracic hairs, by crossing the cuticle (Fig. 2C). Therefore these glands are different from those discribed by Vinson et al (1986), Vinson \& Frankie (1990) and Minckley (1994) in location and morphology.

The glands are present in queens (Figs. 3A, B, 4A, B), workers (Figs. 3C, 4C) and males (Figs. 3D, 4D). They seem to be more developed in queens than in workers and males, having bigger and much cells. In queens, the cells tend to be

TABLE 1

Occurrence of Mesothoracic glands in Meliponinae Bees.

\begin{tabular}{|c|c|c|c|c|}
\hline \multirow[b]{3}{*}{ Species } & \multicolumn{4}{|c|}{ Glandular Occurrence } \\
\hline & \multirow[b]{2}{*}{ Male } & \multirow[b]{2}{*}{ Worker } & \multicolumn{2}{|c|}{ Queen } \\
\hline & & & Virgin & Laying \\
\hline Plebeia remota & + & - & + & - \\
\hline Trigona spinipes & - & + & - & + \\
\hline Trigona recursa & - & + & - & - \\
\hline Schwarziana quadripunctata & - & + & - & + \\
\hline Nannotrigona testaceicornis & + & + & +++ & ++ \\
\hline Scaptotrigona postica & + & + & +++ & ++ \\
\hline Mourella sp & - & + & - & - \\
\hline
\end{tabular}


bigger in the virgin (Figs. 3A, 4A) and smaller and with irregular surface in the physogastric ones (Figs. 3B; 4B). In all individual the cytoplasm shows a clear space around the intracellular canal, considered as indicative of the presence of some secretion. However, when compared virgin and physogastric queens, although the first have bigger glandular cells, the second seem to have more secretion accumulated in them. The secretion appears as an extensive cytoplasmic vacuolization (Fig. 3B). In workers the glands also seem to be more active than in males. The workers have bigger cells, with large nuclei and vacuolated cytoplasm (Fig. 3C).

Thoracic glands constituted by class III cells were reported in ants' metapleural gland by Schoeters \& Billen (1992). The metapleural gland is considered characteristic of ants, not being

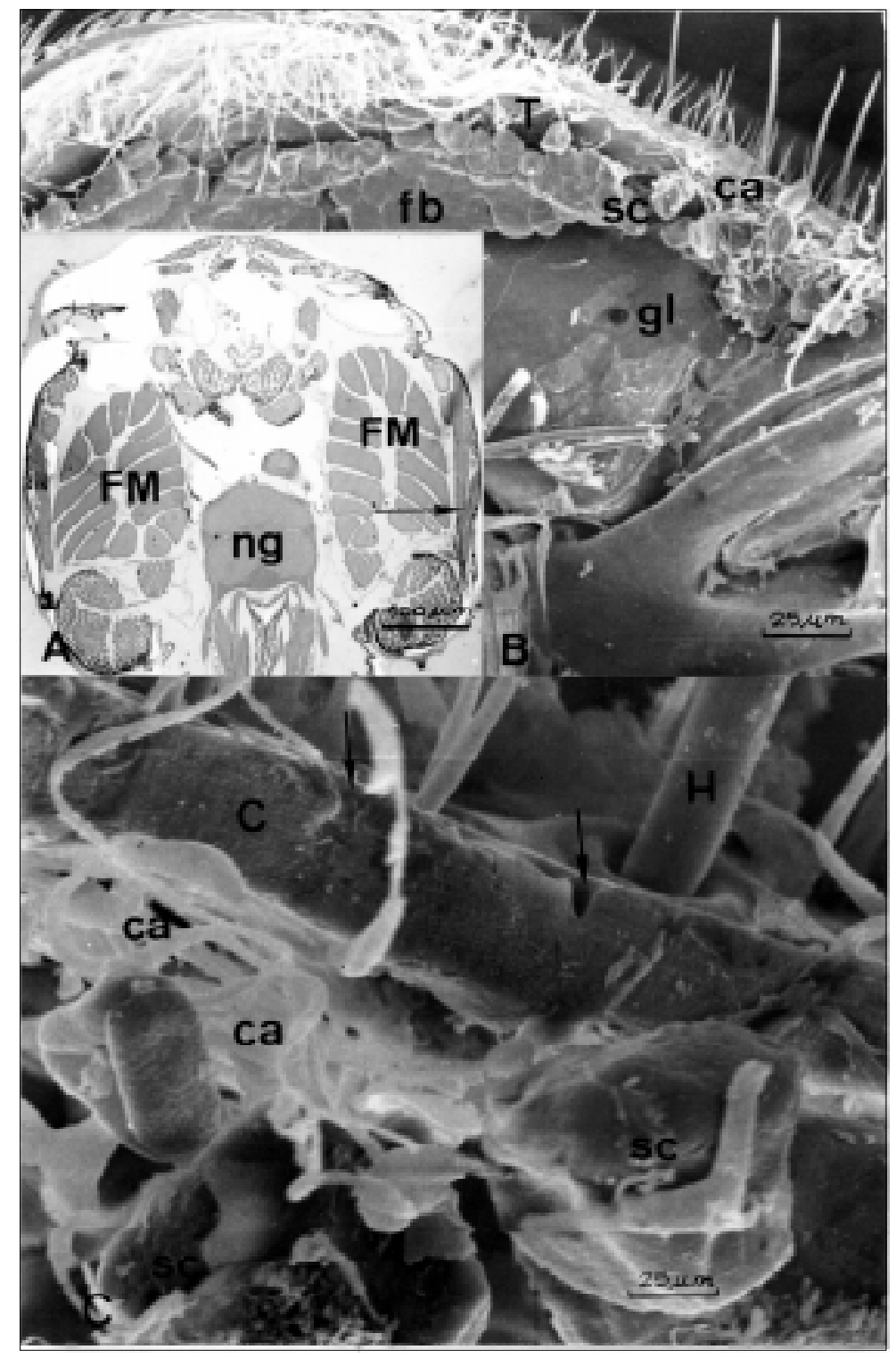

Fig. 1 - Mesothoracic glands (gl) of Scaptotrigona postica. A. Optic micrography of a cross section of the thorax in the mesothorax showing the gland (arrow) locations. B. Scanning electron micrography showing the gland cells (sc) below the tegument (T). C. Scanning electron micrography showing the excretory canals (ca) opennings (arrows) in the cuticle (C ) $\mathrm{fb}=$ fat body $\mathrm{FM}=$ flight muscles; $\mathrm{ng}=$ nervous ganglion; $\mathrm{H}=$ thoracic hair. 
present in other Hymenoptera. But, the reported gland have a location similar to the metapleural and the same type of glandular cell. This is however a preliminar report and more investigation must be done on these and in other species in order to understand correctly the extent of the occurrence of these glands and their possible function.

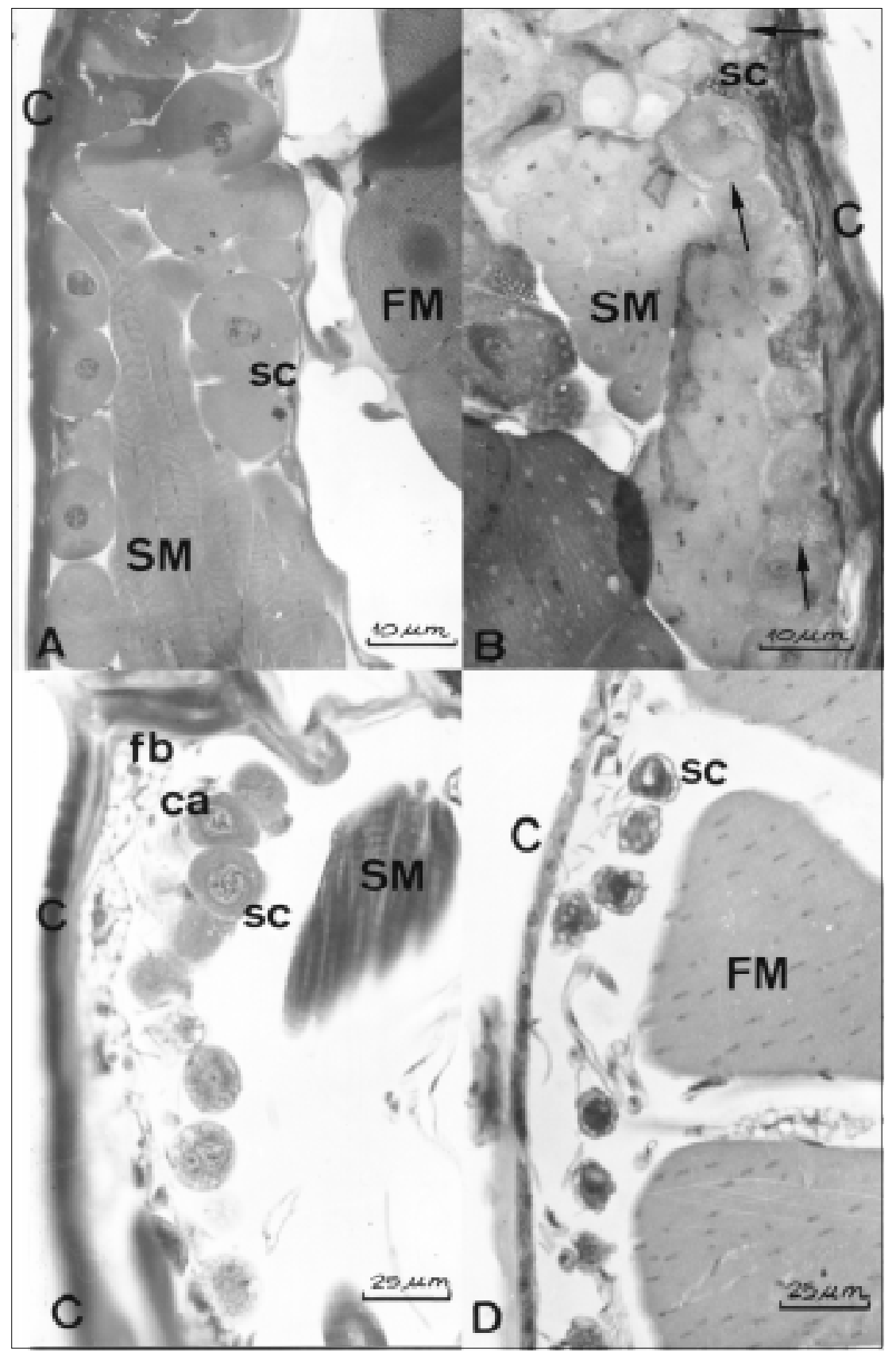

Fig. 2 - Mesothoracic glands of Nannotrigona testaceicornis. A. Virgin queen; B. Physiogastric queen; C. worker; D. male $\mathrm{C}=$ cuticle; $\mathrm{sc}=$ secretory cells; $\mathrm{SM}=$ segmentar muscles; $\mathrm{FM}=$ flight muscles; $\mathrm{ca}=$ excretory canals; $\mathrm{fb}=\mathrm{fat}$ body. The arrows show intracellular secretion. 


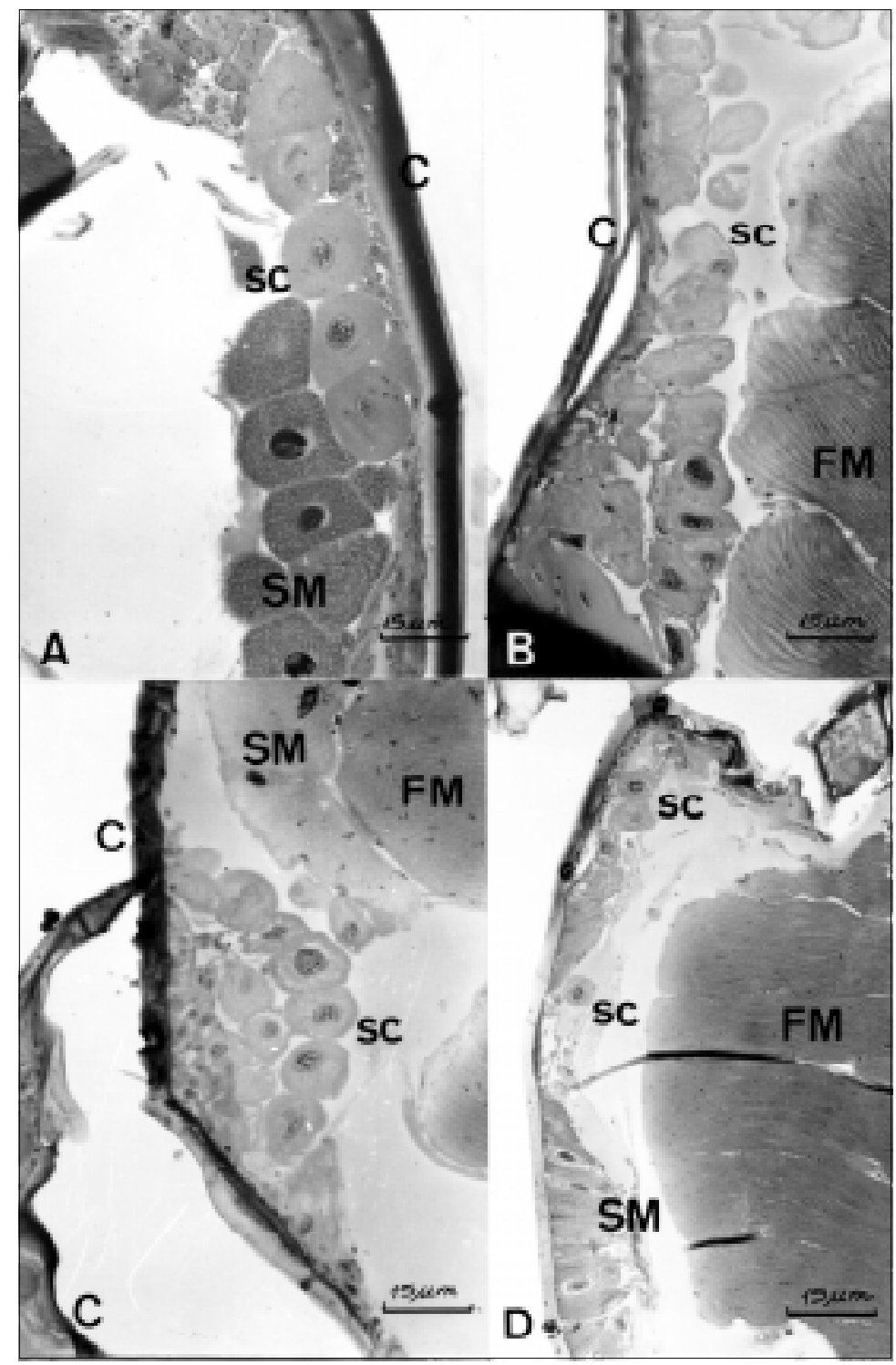

Fig. 3 - Mesothoracic glands of Scaptotrigona postica. A. Virgin queen; B. Physogastric queen; C. worker; D. male. sc = secretory cells; $\mathrm{C}=$ cuticle; $\mathrm{SM}=$ segmentar muscles; $\mathrm{FM}=$ fligh muscles.

\section{REFERENCES}

BORDAS, M. L., 1895, Appareil glandulaire des Hyménoptères. Ann. Sci. Nat. Zool., 19: 1-362.

CRUZ-LANDIM, C., 1963, Evolution of the wax and scent glands in the Apinae (Hymenoptera: Apidae). Jour. N. York Entomol. Soc., 71: 2-13.

CRUZ-LANDIM, C., 1967, Estudo comparativo de algumas glândulas das abelhas (Hymenoptera, Apoidea) e Respectivas Implicações Evolutivas. Arq. Zool. São Paulo, 15: 177-290.
CRUZ-LANDIM, C., HÖFLING, M. C. A. \& IMPERATRIZFONSECA, V. L., 1980, Tergal and mandibular glands in queens of Paratrigona subnuda (Moure) (Hymenoptera, Apidae). Morphology and associated behaviour. Naturalia. São Paulo, 5: 121-133.

CRUZ-LANDIM, C. \& MOTA, M. H. V. B., 1993, Differentiation between the female castes and males of Scaptotrigona postica depilis (Hymenoptera, Apidae, Meliponinae) in the occurrence and ultrastructure of tegumentary exocrine glands. Naturalia, São Paulo, 18: 173-187. 
CRUZ-LANDIM, C. \& SILVA DE MORAES, R. L. M., 1994, Ultrastructural localization of new exocrine glands in legs of social Apidae (Hymenoptera) workers. J. Adv. Zool., 15: 60-67.

DREYLING, L., 1903, Über die wachsbereitenden Organe der Honigbiene. Zool. Auz., 26: 710-715.

HESELHAUS, F., 1922, Die Hautdrüsen der Apiden und verwandten Formen. Zool. Jahrsb., Anat., 43: 369-464.

JACOBS, W., 1924, Das Duftorgan von Apis mellifeca und ähnliche Hautchïsenorgane soziales und solitarer Apiden. Zeitschr. Morph. Ökol Tiere, 3: 1-80.

KOSCHENIKOV, G. A., 1900, Über den Fettkorper und die Oenocyten der Honigbiene (Apis mellifera L.). Zool. Amz., 23: 337-353.

MCINDOO, N. E., 1914, The secent-producing organ of the honeybee. Proc. Nat. Acad. Nat. Sci. Philadephia, 66: 542-555.

MINCKLEY, R. L., 1994, Comparative morphology of the mesosomal gland in male large carpenter bees, Apidae: Xilocopini. Biol. J. Linnean Soc., 53: 291-308.

MOTA, M. H. V. B., 1982, Estudo comparativo das glândulas abdominais relacionadas com o comportamento social em Apidae (Apinae, Meliponinae). Rio Claro, Unesp, 174p. Dissertação de Mestrado em Zoologia, Instituto de Biociências.

MOTA, M. H. V. B., 1988, Estudo comparativo das glândulas epidérmicas do abdómen dos meliponíneos. Rio Claro, Unesp, 235p. Tese de Doutorado em Zoologia, Instituto de Biociências.

MOTA, M. H. V. B. \& CRUZ-LANDIM, C., 1988, Ocorrência e morfometria de glândulas tegumentares abdominais em Apis mellifera (Hymenoptera, Apidae). Rev. Brasil. Zool., 5: 119-154.
NOIROT, C. \& QUENNEDEY, A., 1974, Fine structure of insect epidermal glands. Annu. Rev. Entomol., 19: 61-80.

NOIROT, C. \& QUENNEDEY, A., 1991, Glands, gland cells, glandular units: some comments on terminology and classification. Ann. Soc. Entomol. Fr., 27: 123-128.

RENNER, M. \& BAUMANN, M., 1964, Über Komplexe von sub-epidermalen drüsenzellen (Duftchüsen) der beinenkügen. Naturwissenschaften, 51: 68-69.

RÖSCH, G. A., 1927, Über die Bantätigkeit im Bienenvolk und das alter der Baubienen. Zeitschr. vergl. Physiol., 6: 264-298.

SCHOETERS, E. \& BILLEN, J., 1992, Morphological and ultrastructural study of the metapleural gland in Diacamma (Hymenoptera, Formicidae). In: Biology and Evolution of Social Insects (J. Billen, ed.), Leuwen University Press, Leuven (Belgium), pp. 239-247.

VINSON, S. B., FRANKIE, G. W. \& WILLIAMS, H. W., 1986, Description of a new dorsal mesosomal gland from two neotropical Xylocopa species from Costa Rica. J. K. Entomol. Soc., 59: 185-189.

VINSON, S. B. \& FRANKIE, G. W., 1990, Territorial and mating behavior of Xylocopa fimbriata F. and Xylocopa gualamensis Cockerell from Costa Rica. J. Insect Beh., 3: 12-32.

VINSON, S. B., 1994, Ultrastructure of the mesosomal gland of Xylocopa micans Lepeletier (Hymenoptera: Anthophoridae) associated with pheromone release. Int. J. Insect Morphol. \& Embryol., 23: 243-252. 